論文

\title{
アコースティックエミッション法を用いたリチウムイオン二次電池用 アモルファスシリコン負極の初期劣化損傷評価に関する研究
}

\author{
吉田 尚生* 佐藤 一永** 桑田 直明*** \\ 河村 純一 $* * * *$ 坂本 正 ${ }^{*}$ 橋田 俊之*****

\section{Evaluation of Initial Mechanical and Electrochemical Degradations in Amorphous Silicon Anode for Lithium-Ion Secondary Battery Using AE Method}

by

\author{
Naoki YoshidA*, Kazuhisa SAto**, Naoaki KuwatA***, \\ Junichi Kawamura****, Tadashi SAKamoto* and Toshiyuki Hashida ${ }^{* * * * *}$
}

Silicon is a promising anode material for lithium-ion battery applications because of its high specific capacity. When silicon is lithiated, it undergoes a volume expansion, which may lead to extensive damage. This is thought to be a primary cause of the rapid decay in the cell capacity. Amorphous silicon (a-Si) has been recently suggested to possess a higher resistance to the lithiation-induced cracking compared with crystalline silicon (c-Si). This paper presents some experimental results of charge-discharge tests conducted on a cell composed of a-Si negative electrode and $\mathrm{Li}$ metal. An acoustic emission (AE) technique was employed to carry out in-situ monitoring of the mechanical damage during the tests. A number of $\mathrm{AE}$ signals were detected on the first lithiation in the a-Si negative electrode and the $\mathrm{AE}$ activity decreased drastically on the subsequent cycles. Examination of frequency components of the AE signals obtained in the tests identified two types of events: one type from silicon cracking, and the other type from the gas generation. The AE results suggested that the mechanical damage due to the lithiation and delithiation took place primarily on the first cycle.

\section{Key words:}

Li-ion battery, Silicon electrode, Acoustic emission, Mechanical damage, Battery capacity

\section{1 緒言}

リチウムイオン電池は高い電圧と高いエネルギー密度 を持つことから，パソコンやスマートホン等の携帯型電 子機器の電源として広く利用されている。また, 最近で は電気自動車 $(\mathrm{EV})$ や災害時のバックアップ電源として も使用されはじめている。特に，近年注目が集まってい る EV は高出力かつ大容量の電池が必要であることから, リチウムイオン電池のさらなる高容量化が求められてい る. 電池容量の向上には, 充放電に関わる正極活物質, 負極活物質の高エネルギー密度化が必要不可欠である. 高容量化が期待される負極材料として, 従来用いられて いる黒鉛 $\left(\mathrm{LiC}_{6}\right.$ の化学組成における容量密度 : $\left.370 \mathrm{mAh} / \mathrm{g}\right)$ 1) に代わり，シリコン $(\mathrm{Si})$ 負極 $\left(\mathrm{Li}_{15} \mathrm{Si}_{4}\right.$ の化学組成にお ける容量密度 : $4200 \mathrm{mAh} / \mathrm{g}$ ) 2),3) が注目されている。し かしながら，Si 負極は充放電時に Li の挿入・脱離により 大きな体積変化が生じ，微粉化することによりサイクル 寿命が短くなることが報告されている ${ }^{4)}$,5). 特に，初期
充電時にはリチウム（Li）イオンが結晶性 Si（以降, c-Si と略称）の内部に拡散する過程でアモルファス化しなが ら膨張していくことが知られており，不可逆容量が大き く劣化することが報告されている ${ }^{6)}$. 現在, この問題を解 決するために，あらかじめアモルファス化したアモルフ アスシリコン (以降, a-Si と略称) の活用が考えられてお り, a-Si で構成される電池の負極, a-Si ナノワイヤーやナ ノチューブの使用が有効な対策として提案されている 3) ,7) 9). a-Si は, 合金化の際に, 結晶相とアモルファス 相の 2 相界面の形成を抑制できることや, 結晶面に依存 しない均一な膨張が生じることから初期充放電過程にお ける容量劣化を抑制できることが報告されている ${ }^{3), 7) ~ 9) . ~}$ このように, a-Si の有効性については示唆されているもの の, 充放電過程における劣化挙動の詳細については未解 明の課題となっている. Si 負極の劣化に対して, 有効な 対策を検討するためには充放電中に電池内部で起きる $\mathrm{Si}$ 負極の損傷挙動を解明する必要がある。しかしながら,

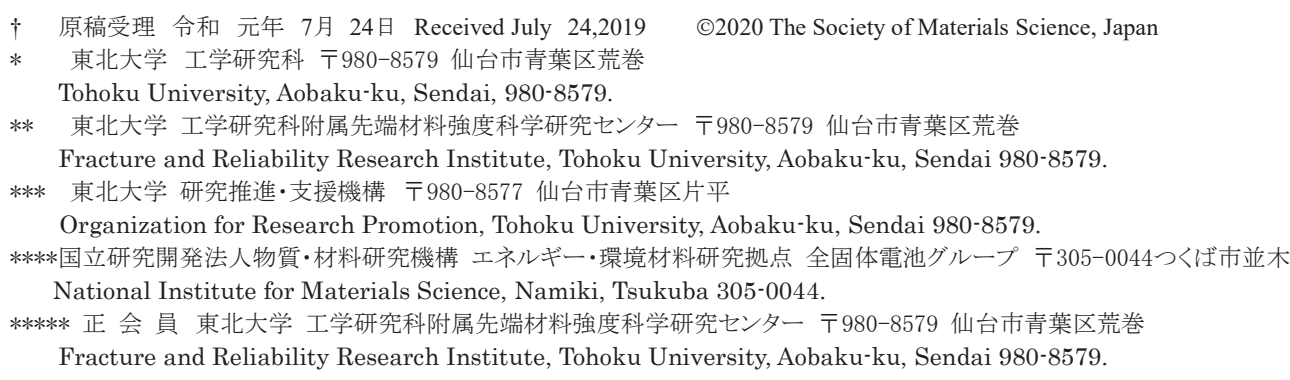


Li は水と極めて高い反応性を有することから，大気中に 開放できず，充放電中のリチウムイオン電池内部の損傷 挙動を大気中で評価することが容易ではない. そのため, 従来の電気化学的評価のみならず, 充放電中にその場で 電池内部に発生する機械的損傷を検出できる評価手法が 求められている。 そのために, $\mathrm{AE}$ 法 ${ }^{4)}$,5),10) 13), MOSS 法 ${ }^{14)}$, TEM 観察 $\left.\left.{ }^{8)}, 15\right), 16\right)$, SEM 観察 ${ }^{17)}$, 光学顕微鏡観察, AFM 観察 ${ }^{18)}$ などを用いた研究が活発に行われてきてい る.これらの手法の中でも, $\mathrm{AE}$ 法は機械的損傷のモ二 タリング手法として, ニッケルマンガン電池やリチウム イオン電池の $\mathrm{MnO}_{2}$, グラファイト, $\mathrm{NiSb}_{2}, \mathrm{Al}, \mathrm{Si}$ など の電極材料の評価に利用され始めている. c-Si 負極を有す るリチウムイオン電池の評価に $\mathrm{AE}$ 法が適用された報告 例があるものの ${ }^{4)}$,5) , a-Si 負極を対象とした検討は未だ実 施されていない。本研究では，上述の背景を基に，a-Si 負極の充放電サイクルに伴う劣化挙動を詳細に解明する ことを目的に, 非破壊評価手法として AE 法を併用したセ ルの充放電試験を行い, 電気容量の充放電サイクルによ る劣化挙動を機械的損傷との関係の観点から検討する.

\section{2 試験片作製方法および実験方法}

\section{$2 \cdot 1$ ハーフ電池セルの試作と分析}

本研究では, 充放電試験用に a-Si を負極, Li を正極, ならびに有機電解液を用いたハーフ電池セルを試作した。 また，負極の集電体として $\mathrm{Cu}$ 基板を用いた.

まず，パルスレーザーデポジション（PLD） 法を用い て, $\mathrm{Cu}$ 基板上に負極としての a-Si 薄膜をコーティングし た. コーティングした a-Si 薄膜は見かけ嵩密度 $98 \%$ 以上 であることを確認した. PLD には, 第 3 高調波の Nd:YAG レーザー発振装置 （波長 355 nm; Quanta-Ray INDI Pulsed Nd:YAG Laser, Spectra-Physics）を用いた。 a-Si 膜材の原 料として Si ターゲット（純度 $99.9 \%$ ，(株）豊島製作所） を使用した．基板として用いた $\mathrm{Cu}$ は $8 \mathrm{~mm} \times 8 \mathrm{~mm} \times 0.02$ $\mathrm{mm}$ 寸法の正方形銅箔（純度 $99.9 \%$, (株) ニラコ社）で ある、銅箔は, a-Si 膜との密着性を高めるために, \#400 のエメリー紙を用いて表面研磨したものを用いた，成膜 は表面研磨を行った銅䈃を真空チャンバーの中に設置し, $5.0 \times 10^{-4} \mathrm{~Pa}$ 以下の真空環境下で行った. 作製した試料 の結晶構造を調べるために，X 線回折装置（銅管球,

MAXima_X XRD-7000,（株）島津製作所）を用いて X 線回折による定性分析を行った。また作製した試料の表 面形状を観察するために走査型電子顕微鏡（JSM-6610, 日本電子（株）, 以降, SEM と略称）を用いた。

正極には円形状で寸法が $\phi 10 \mathrm{~mm} \times 1.0 \mathrm{~mm} の \mathrm{Li}$ （純度 $99.9 \%$, Sigma-Aldrich) を用いた。電解質は, ガラスセパ レータ (PP-2400, Celgard LLC) に $1 \mathrm{~mol} / \mathrm{L} \mathrm{LiPF}_{6}$ を添加し たエチレンカーボネートバメチルカーボネート混合溶液

（混合比 1:1）を含浸させることにより形成した. 用いた $\mathrm{Li}$ と有機電解液は, 水分と容易に反応寸るため, 大気中 においては電池セルを組立てることはできない. そこで,
電池セルの組立ては, 以下に記載するセルホルダーをグ ローブボックス内部に設置することにより行った.

\section{$2 \cdot 2$ 充放電試験と $\mathrm{AE}$ 測定}

本試験で用いたセルホルダーならびに充放電評価装置 の模式図を Fig. 1 に示す. セルホルダーは, 内径 $30 \mathrm{~mm}$, 外径 $48 \mathrm{~mm}$ の SUS304 製の円筒容器 2 つを円筒形状の PTFE で連結させた構造を有する. 電池セルは下部円筒容 器の底部に設置される. セルホルダー内に電池セルを組 立てるために，まず，セルホルダーを分解し，エタノー ルで洗浄した各部品を SUS306 製の真空デシケーターに 入れ, $80{ }^{\circ} \mathrm{C}$ 恒温槽内で少なくとも 6 時間以上の真空乾 燥を行い, セルホルダー内の水分を除去した. 室温まで 冷却した後, グローブボックス内で上述した真空デシケ ーターから部品を取り出し, セルホルダーの下部円筒容 器を用いて, 電池セルを組立てた. 集電体である $\mathrm{Cu}$ 基板 上にコーティングした負極である $\mathrm{a}-\mathrm{Si}$ を $\mathrm{Cu}$ 基板側が容器 底部に接するように設置し， a-Si の上に有機電解液を含 浸させたガラスセパレータ，さらに正極としての Li 箔を 積層することにより電池セルを構成する. その後, 円筒 型PTFE を挿入し, 上部ならびに下部円筒容器を組合わせ た. なお, この時, 電池セルは, ホルダー内上部の SUS304 製のスペーサーを介してコイルばねにより下部円筒容器 の底部に密着される。これにより, Li と上部円筒容器が 導通し, $a-\mathrm{Si} / \mathrm{Cu}$ と下部円筒容器が導通する. 一方, 上部 および下部円筒容器は O リングを介することにより完全 に絶縁した. 以上の電池セルならびにセルホルダーの組 立ては，すべての過程において湿度を制御したグローブ ボックス内で行った.グローブボックス内には Arガス (純 度 $99.9999 \%$ ）を流動させることにより露点温度-80 ${ }^{\circ} \mathrm{C}$ 以 下の条件を保持した．グローブボックス内の露点温度は 露点計を用いて観測した.

電池セルの充放電特性を評価するために, セルホルダ ーとポテンショスタット (VMP-3, Bio-Logic Science Instruments）を接続した。 上部円筒容器は対極と，下部円 筒容器は作用極と接続した. 本研究では充放電試験の実 施にあたり CCCV (Constant Current-Constant Voltage) 試 験法を用いた。

充電時には $90 \mu \mathrm{A}$ で定電流充電を行い，電圧を開放端 電圧すなわち初期電圧である $2 \mathrm{~V}$ から $1 \mathrm{mV}$ まで降下させ た. その後, 電圧 $1 \mathrm{mV}$ において 3 時間の定電圧充電を行 った. 放電時には $90 \mu \mathrm{A}$ で定電流放電を行い, セル電圧 を $2 \mathrm{~V}$ まで上昇させた後, $2 \mathrm{~V}$ で 3 時間の定電圧放電を行 った. 定電流充放電過程で採用した電流 $90 \mu \mathrm{A}$ は, 本研 究で試作した電池セルの理論容量を 10 時間で充放電完了 できる電流值に相当し，Cレートとの関係で示すと $0.1 \mathrm{C}$ に対応する.ここで, Cレートとは所定の電池セルに対し て 1 時間で充放電が完了する電流值を $1 \mathrm{C}$ と定義するも のである. $1 \mathrm{mV}$ での定電圧充電と $2 \mathrm{~V}$ での定電圧放電を 3 時間実施することで, 電流はほぼ零になることを観察し ており, これらの定電圧充電・放電を行うことにより, 
Li と $\mathrm{Si}$ の反応が完了していることを確かめている．本研 究においては, 5 サイクルまでの充放電サイクル試験を実 施している.

また充放電サイクル試験と同時に $\mathrm{AE}$ 測定を実施した. 電池セル上に設置した SUS304 製スペーサーおよびコイ ルばねは，電池セルと下部円筒容器との導通を図ってい るとともに，AE信号の減衰を低減させている。 $\mathrm{AE}$ セン サー（AE-900S-WB，エヌエフ回路設計ブロック）は，電 池セル直下の下部円筒容器壁にシリコングリースを介し て設置し，コイルばねにより密着させている．検出され た $\mathrm{AE}$ 信号はプリアンプ $(40 \mathrm{~dB})$ で増幅した後，ハイパ スフィルター（遮断周波数 $20 \mathrm{kHz}$ ) とローパスフィルタ

（遮断周波数 $500 \mathrm{kHz}$ )を介して,さらにメインアンプ(40 dB）で増幅した後，オシロスコープに記録した。したが い, $\mathrm{AE}$ 測定の総合検出利得は $80 \mathrm{~dB}$ である。サンプリン グ周波数は $100 \mathrm{MHz}$ とした。充放電に伴う現象解明を目 的として，記録された $\mathrm{AE}$ 信号の周波数解析を行った。ま た充放電試験前後の電池セルを SEM を用いて観察し, $\mathrm{AE}$ 信号の周波数解析結果と組合わせて比較検討を行った.

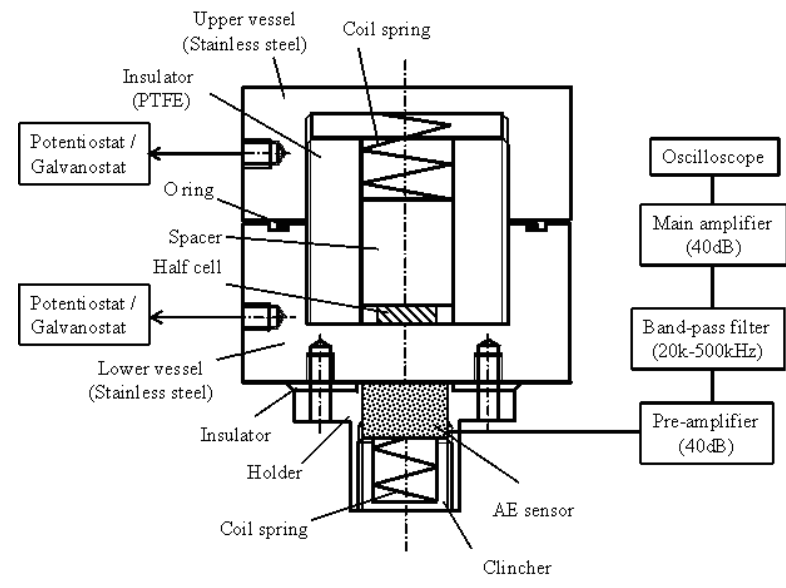

Fig.1 Schematic diagram of an experimental setup.

\section{3 実験結果と考察}

\section{$3 \cdot 1$ 試作した Si 負極の膜構造}

本研究で試作した Si 負極の X 線回折結果と SEM 観察 結果について記述する．Si 負極について，X 線回折で得 られた回折角之強度の関係を Fig. 2 に示寸. X 線回折で検 出されたピークは $\mathrm{Cu}$ 基板由来のピークのみである。これ らのことから，成膜された Si 負極はアモルファスである ことを確認することができる．PLDで作製した a-Si 膜の 厚さは，表面粗さ計を用いて基板と膜表面との段差を計 測することにより，2 2 m 程度であることがわかっている また, a-Si 成膜の前後における重量測定の結果と計測され た a-Si 膜の厚みに基づく評価により，作製された a-Si 膜 はほぼ緻密なものであることが示されている。

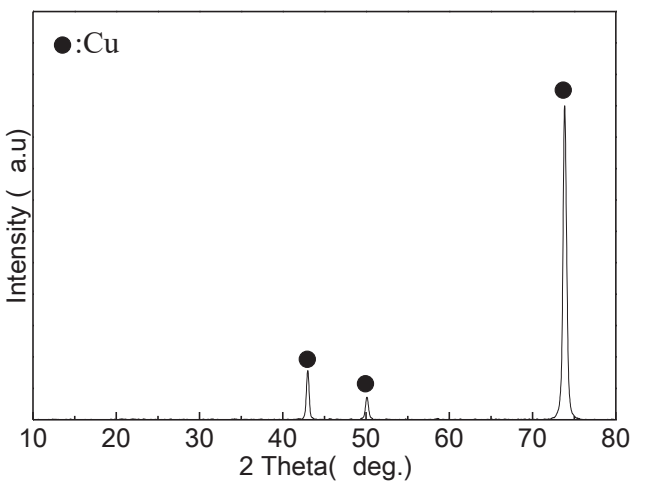

Fig. 2 XRD pattern of the amorphous silicon thin film prepared by pulse laser deposition.

\section{$3 \cdot 2$ 電位履歴と累積 $\mathrm{AE}$ エネルギー}

電池セルの充放電サイクル試験の結果について記述す る. Fig. 3 に，初期の充放電 3 サイクルにおけるセル電圧 ならびに, 検出された $\mathrm{AE}$ 信号の累積 $\mathrm{AE}$ エネルギーの時 間変化を示す． AE 信号はサンプルからセルを経由して検 出されるが, セルから $\mathrm{AE}$ センサの距離や $\mathrm{AE}$ センサの接 触部の影響をうけて $\mathrm{AE}$ 信号が減衰することから， $\mathrm{AE}$ エ ネルギーの算出にはいくつかの方法がある。本研究では 持続時間よりも，振幅の違いが大きく影響を及ぼすため, 一般的に多く用いられる， $V^{2}$ s を採用した ${ }^{19)}$. 1 サイクル 目は 0 21 時間, 2 サイクル目は21 41.5 時間, 3 サイクル 目は 41.5 62 時間の時間帯にそれぞれ対応している. また 1 サイクル目のみに着目した充電過程と放電過程のセル 電圧ならびに累積 $\mathrm{AE}$ エネルギーの時間変化をそれぞれ Fig. 4(a) と(b)に示す. Fig. 4(a)が充電過程, Fig. 4(b)は放電 過程を示している. 充放電過程の電圧・電流条件につい て，1 サイクル目を例として記載すると，Fig. 4(a)におい て 0 10.5 時間が充電過程で，その中の 0 7.5 時間は定電 流条件であり, それ以降の 3 時間は定電圧条件である. また, Fig. 4(b)は放電過程を示す. 10.5 17.5 時間までは定 電流条件であり, それ以降の 3 時間においては定電圧放 電で行った。実験方法に記載したように，各サイクルの 充放電過程で, 定電流過程に加えて 3 時間の定電圧過程 を行うことで電池反応を完全に生じさせた。充電過程に おいて，充電開始時の電圧はおよそ $2.0 \mathrm{~V}$ 程度であり，そ こから $0.4 \mathrm{~V}$ までは急激にセル電圧が減少し， $0.4 \mathrm{~V}$ 以下 では緩やかな電圧低下が起きる領域が生じた。 また放電 過程においても, およそ $0.5 \mathrm{~V}$ 以下でセル電圧の変化が緩 やかな領域が観察された後, 急激なセル電圧の増加が観 察される. したがい, 充電過程と放電過程の両方の過程 において $0.4 \mathrm{~V}$ 以下で電圧の変化が緩やかな領域が生じ ている。この領域は，a-Si 負極と Li イオンとの合金化反

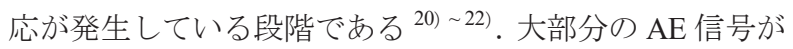
1 サイクル目の定電流充電過程で検出されている. 2 サ イクル目および3サイクル目においても AE信号は検出さ れたが，1 サイクル目と比べてその $\mathrm{AE}$ 活性は極めて低い ことがわかる. Fig. 4(a)と(b)に詳細が示されている 1 サイ クル目の充放電過程における電圧変化と $\mathrm{AE}$ 挙動を比較 
する. 充電に伴いセル電圧が低下し, 約 $0.4 \mathrm{~V}$ になった時 点から $\mathrm{AE}$ 信号が検出されていることがわかる. およそ充 電開始から 1 時間後にはほぼ $\mathrm{AE}$ 信号のエネルギーは飽和 する傾向にある，それに対して放電過程においては，セ ル電圧が急激に増加する以前の段階において再度 $\mathrm{AE}$ 活 性度が高くなっていることが観察される。初期の充放電 過程において，Si 負極と電解液界面において極めて薄い 反応層 (Solid Electrolyte Interface Layer;以降 SEI 層と略称) が形成されること，さらに，この反応過程において炭化 水素系のガスが発生することが知られている $\left.{ }^{3)}, 23\right)$.さら に SEI 層の形成とガス発生はセル電圧の変化が緩やかな 領域の初期段階, 寸なわち約 $0.4 \mathrm{~V}$ で生じることがわかっ ている.事実，同じセルを対象として，レーザー顕微鏡 を組み込んだ電池性能評価装置を用いた著者らの研究 ${ }^{23)}$ において，セル電圧が約 $0.4 \mathrm{~V}$ の段階において $\mathrm{Si}$ 負極表 面でガス発生を観察している。したがって，Fig. 4(a)に示 される約 $0.4 \mathrm{~V}$ の段階で放出が開始される $\mathrm{AE}$ 信号は, 上 述の SEI 層形成に伴うガス発生に起因する AE 信号を含む ものと推察される.

Fig. 5 に 1 サイクル目の充放電サイクル試験前後にお ける $\mathrm{Si}$ 負極表面の SEM 像を示している. 充放電サイクル 試験以前の初期の $\mathrm{Si}$ 負極表面の SEM 像を Fig. 5(a)に，充 放電サイクル試験後のものを Fig. 5(b)に示している. Fig. $5(\mathrm{~b})$ より，Si 負極は 1 サイクル目において顕著に損傷し， 脱落破壊が生じていることがわかる。しかしながら，Si 負極は全面的に $\mathrm{Cu}$ 基板から脱落しているのではなく, 寸 法が㧍よそ $10 \mu \mathrm{m}$ 程度の島状の $\mathrm{Si}$ 負極層が数多く $\mathrm{Cu}$ 基 板上に残存していることが観察される. Si 負極にLiイオ ンが合金化反応によって挿入され，Si 負極層が膨張する ため面内に圧縮負荷を受け，座屈破壞に起因した脱落破 壊が発生しているものと考えられる。このことから，Fig. 3 で観察された $\mathrm{AE}$ 信号は先に述べたガス発生だけではな $<, \mathrm{Si}$ 負極の機械的損傷に由来寸る $\mathrm{AE}$ 信号も検出してお り, 2 つの $\mathrm{AE}$ 信号が混在して検出されていると推察され る.

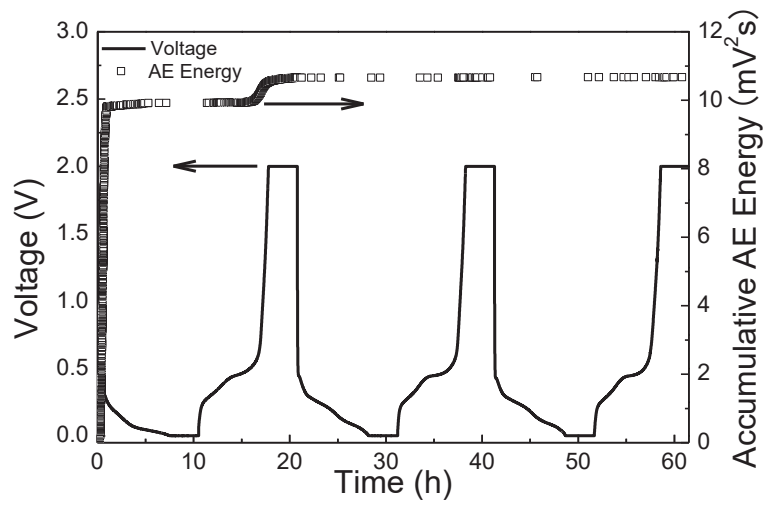

Fig. 3 Typical evolution of electrode potential and accumulated $\mathrm{AE}$ energy in the first 3 cycles.
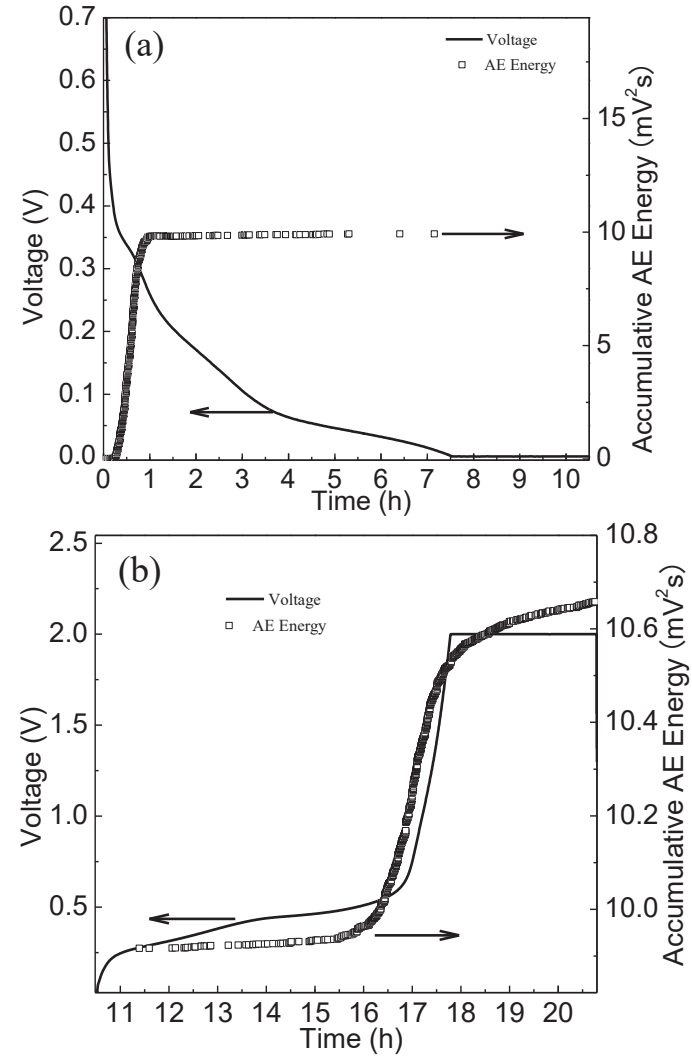

Fig. 4 Typical evolution of electrode potential and accumulated $\mathrm{AE}$ energy during the first cycle for (a) charge process and (b) discharge process.
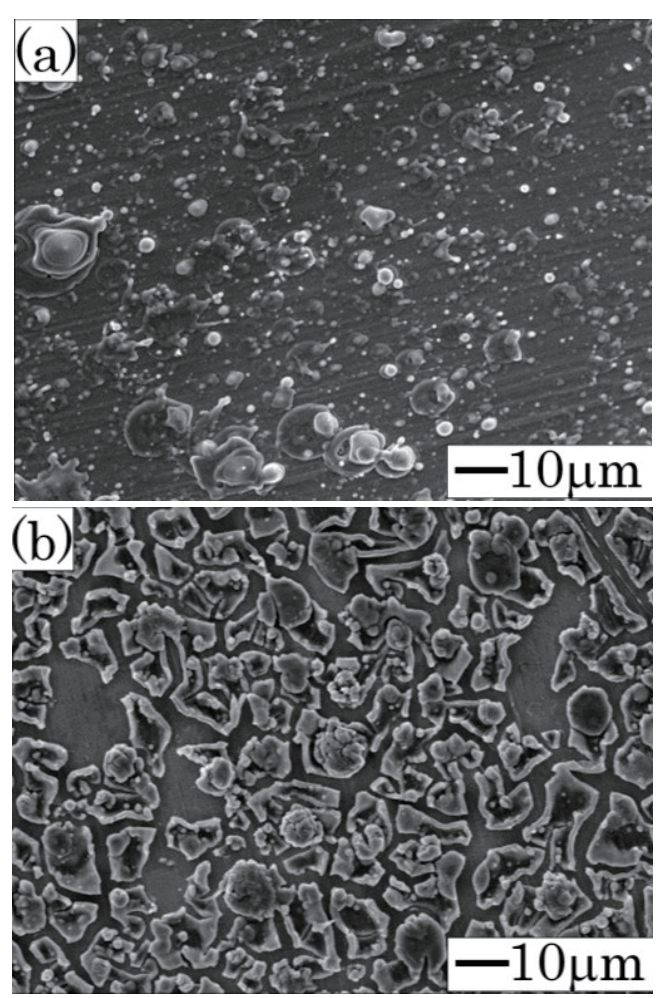

Fig. 5 SEM images of the amorphous silicon thin film (a) as deposited using pulse laser deposition, and (b) after charge-discharge cycling test. 


\section{$3 \cdot 3 \mathrm{AE}$ 信号と周波数解析}

本研究で検出された $\mathrm{AE}$ 信号は, それらの周波数スペク トルに基づき， 2 種類に分類されうることがわかった. 2 種類の信号をそれぞれ Type A ならびに Type B と呼ぶこと とする. Type A と Type B の代表的な波形と周波数スペク トルを Fig. 6 と Fig. 7 に示す. 20〜 40 kHz 領域の最大強度 が他の領域に比べ 10 倍以上の信号を Type A とし，190〜 $200 \mathrm{kHz}$ 領域の最大強度が 20〜 40 kHz 領域の最大強度の 3 割以上検出された信号を Type B として分類した。なお， AE 信号の振幅においては，Type A と Type B との間に明 確な差異は認められていない。前述したように，1 サイ クル目の充放電過程においては Si 負極の機械的損傷とガ ス発生が確認されていることに対して，レーザー顕微鏡 を用いた観察 ${ }^{24)}$ に基づけば，2 サイクル目以降には $\mathrm{Si}$ 負 極の割れが進行するもののガス発生は生じていない.c-Si 負極を対象とした， $\mathrm{AE}$ 法を用いた既存の研究において， ガスが発生する際の AE 信号は $100 \mathrm{kHz}$ 以下にピークを持 ち， $\mathrm{Si}$ 負極の割れに対応する $\mathrm{AE}$ 信号は $100 \mathrm{kHz}$ 以上の ピークを持つと報告されている ${ }^{4)}$ ，5)。現状ではガスの発 生と $\mathrm{Si}$ の損傷のそれぞれの周波数スペクトルを決定する 要因は明らかにはなっていないものの，当グループが過 去に報告した $\mathrm{AE}$ 法と顕微鏡観察を併用した試験におい て, 本研究と同様の電解液のガスの発生時に $100 \mathrm{kHz}$ 以下 の信号が検出される実験的事実を確認している ${ }^{25)}$. 以上 の知見に基づくと， Type A の AE 信号は電解液の分解に よるガス発生に起因するものであり，Type B の AE 信号 は Si 負極の機械的損傷によるものであると考えられる. リチウムイオン電池において，ガス発生は電解液と電極 の接触を阻害することにより内部抵抗の増加をもたらす ことが知られており, 上述の $\mathrm{AE}$ 信号の周波数解析結果か ら, 電池セルの劣化メカニズムを解明する上で重要な知 見が得られることを示唆している.

Fig. 8 に 1 サイクル目の初期充放電サイクルにおける, Type A および Type B の AE 活性度の電圧に対する変化挙 動を示している. 充電時の結果を Fig. 8 (a) に放電時の結 果を Fig. 8 (b) に示している. 1 サイクル目では充電時と 放電時のいずれにおいてもガス発生と $\mathrm{Si}$ 負極損傷が同時 に起きていることが観察される．特に充電時の初期には 大きなエネルギーを有する AE信号が検出されている. Fig. 3 では, 充電時における電圧変化が緩やかな領域の初期で $\mathrm{AE}$ 信号の活性度が増大寸ることが示されている. Fig. 8 (a) で観察される大きなエネルギーの $\mathrm{AE}$ 信号の発生はそ の領域に対応している. また 1 サイクル目の放電時にお いても, ガス発生に起因する Type A の AE 信号と $\mathrm{Si}$ 負極 の機械的損傷に起因する Type B の AE 信号が検出されて いる. 通常，リチウムイオン電池の電極材料における SEI 層の形成は主に充電過程で行われる。しかしながら，Fig. 8(b)の結果から放電中にもガスの発生が起きていること から，Si 負極においては充電過程のみではなく放電過程 でも SEI 層の形成反応が起こっているものと考えられる.
これは 1 サイクル目の放電時にガスの発生と同時に $\mathrm{Si}$ 負 極の損傷が発生していることから，リチウムイオンの脱 離に伴い $\mathrm{Si}$ 負極が損傷寸ることで新しく $\mathrm{Si}$ 負極と電解液 の接触面が形成されるためであると推察される.
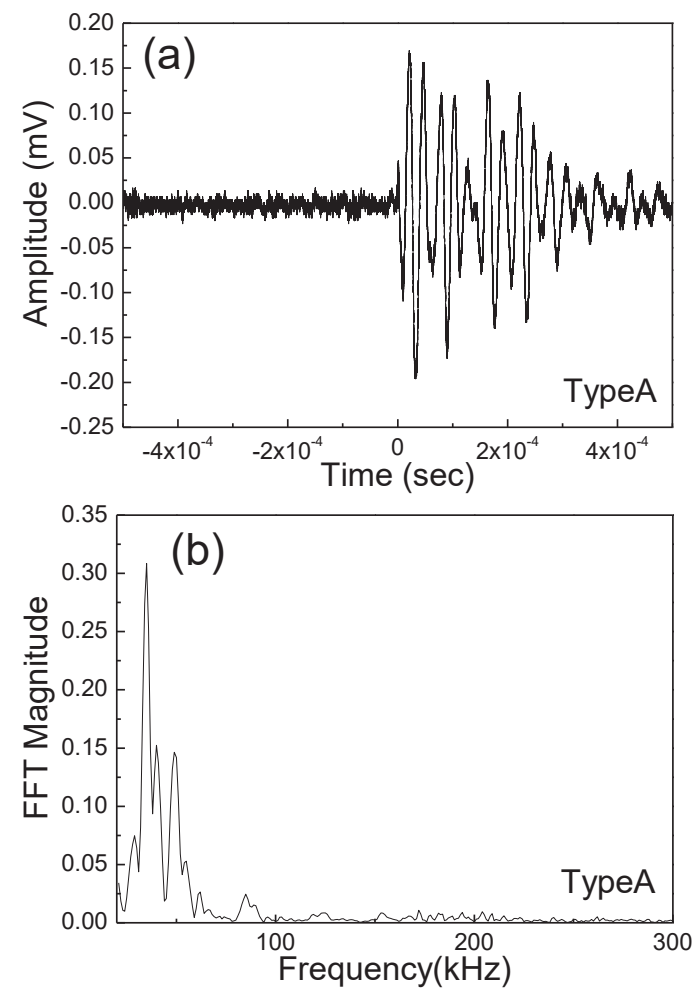

Fig. 6 Typical example of Type A AE signals (a) waveform and (b) fast Fourier transform spectra.
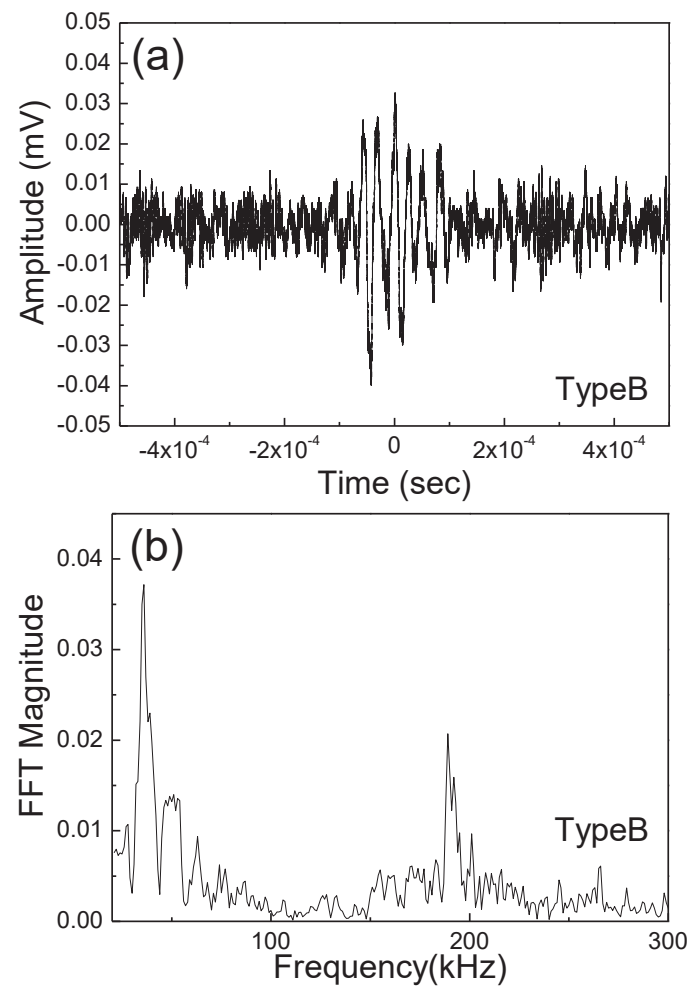

Fig. 7 Typical example of Type B AE signals (a) waveform and (b) fast Fourier transform spectra. 

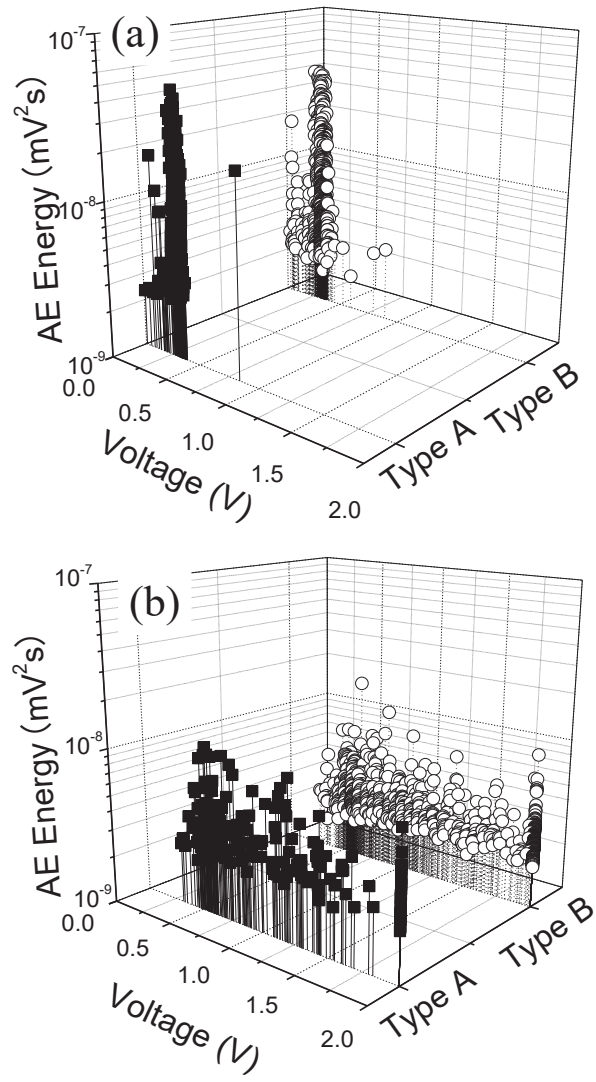

Fig. 8 AE energy plotted against the cell voltage for Type A and B signals in the first cycle. (a) charge process, and (b) discharge process.

\section{$3 \cdot 4 \quad \mathrm{AE}$ 活性度と電池容量}

充放電サイクルに伴う $\mathrm{a}-\mathrm{Si}$ の容量と $\mathrm{AE}$ 活性度との関 係を Fig. 9 に示す. 横軸のサイクル数の記載においては, 充放電サイクル試験の開始以前を 0.0 サイクルとし, 初回 の充電過程を 0.5 サイクル, 初回の放電過程を 1.0 サイク ルと表現している.1 サイクル目における初期充電容量は c-Si 負極の初期充電容量が $3200 \mathrm{mAh} / \mathrm{g}^{2)}$,3) 程度であるの に対し本研究で用いた a-Si は $3900 \mathrm{mAh} / \mathrm{g}$ とほぼ理論值通 りの高い值を示した．このことから $\mathrm{Si}$ 負極をアモルファ スにすることで初期充電時において，Li と $\mathrm{Si}$ の反応をよ り促進させうることがわかる。これは Li イオンの a-Si へ の拡散係数が大きいことに起因する結果であると推察さ れる ${ }^{26)}$.

また 1 サイクル目における放電後の容量は $3600 \mathrm{mAh} / \mathrm{g}$ の容量を示しており, その減少率は 8 \%程度であった。こ の容量の減少率はFig.5 で示した Si負極の脱離量におおむ ね一致しており, この容量の減少は $\mathrm{Si}$ 負極の脱離により 起きていると考えられる.

ここで $\mathrm{AE}$ 活性度パラメータに注目する。 $\mathrm{AE}$ 活性度 は 1 サイクル目の充放電過程に卓越し, 2 サイクル目以降 には 1 サイクル目と比較して急激に低下することが観察 される.これは充放電サイクルに伴う容量変化と類似し ており, 電気的容量劣化は Si 負極の機械的損傷ならびに ガス発生に起因しているものと考えることができる。さ
らに，2 サイクル目以降の充放電過程においては， $\mathrm{AE}$ 信 号の活性度はきわめて低いものとなっている. 上記の $\mathrm{AE}$ 活性度の変化傾向は, 1 サイクル目にほぼ完全な反応が生 じているため 2 サイクル目以降において $\mathrm{AE}$ 活性度が極め て小さかったためと推察される.

Fig. 10 に, 2 サイクル目と 3 サイクル目におけるセル電 圧ならびに, 検出された $\mathrm{AE}$ 信号の累積 $\mathrm{AE}$ エネルギーの 時間変化を示す。 2 サイクル目以降になると, $\mathrm{AE}$ 活性度 は初期サイクル目に対して小さくなるものの, 充電過程 ではなく放電過程で主体的に $\mathrm{AE}$ 信号が検出されるよう になった. 同様に, 容量の減少も 2 サイクル目以降にな ると充電過程よりも放電過程で大きくなった．これは初 期サイクルに膨張により座屈破壊が十分に進行したこと で, 2 サイクル目以降では充電過程で生成された SEI 層の 破壊が放電過程の収縮時に起きることで $\mathrm{Si}$ 負極が微粉化 しながら損傷するためであると考えられる。この現象は 当グループが過去に行ったレーザー顕微鏡観察の結果に よって確認している ${ }^{24)}$.

電池の充放電サイクルに伴う容量劣化挙動を特徵付け るためにしばしばクーロン効率が用いられる。ここで, クーロン効率は各サイクルに対して, 放電容量を充電容 量で除したものである. Fig. 9 を基に, クーロン効率とサ イクル数との関係図を Fig. 11 に示す. 1 サイクル目にお いてクーロン効率は 92 \%だったのに対して， 2 サイクル 目以降は 1 サイクル目に比べ極めて大きくなった. 本研 究では, AE 法を併用することにより, Li イオン電池の充 放電サイクルに伴う容量劣化を機械的損傷の観点から検 討し, 1 サイクル目と 2 サイクル目以降の劣化過程の差異 を明らかにした．また $\mathrm{AE}$ 法を活用することで $\mathrm{Si}$ 負極で の長期的な容量の減少が電極部の機械的損傷による生じ ることを明らかにした。このことから AE 法が $\mathrm{Si}$ 負極の サイクル特性を改善する上で有用な測定手法であること を示した. また今回用いた $\mathrm{AE}$ 法は電解液を用いた電池に だけではなく, 現在注目されている全固体電池の評価に も有用なものである.

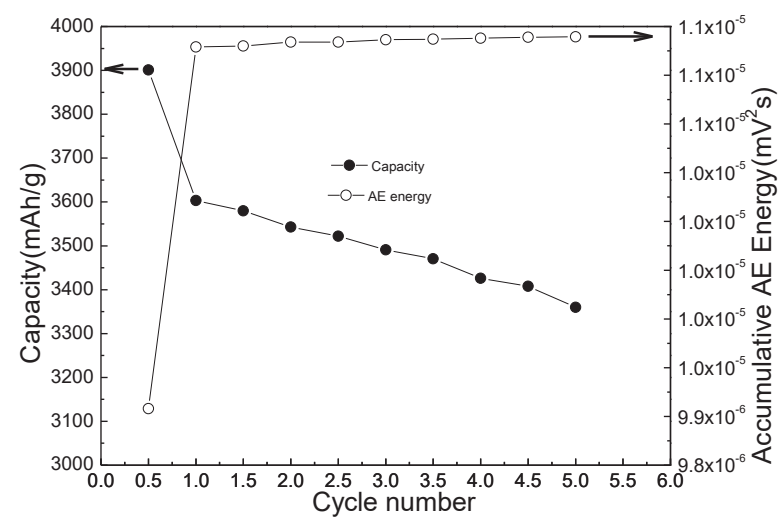

Fig. 9 Evolution of the cell capacity and AE activity for amorphous silicon and crystalline silicon. 


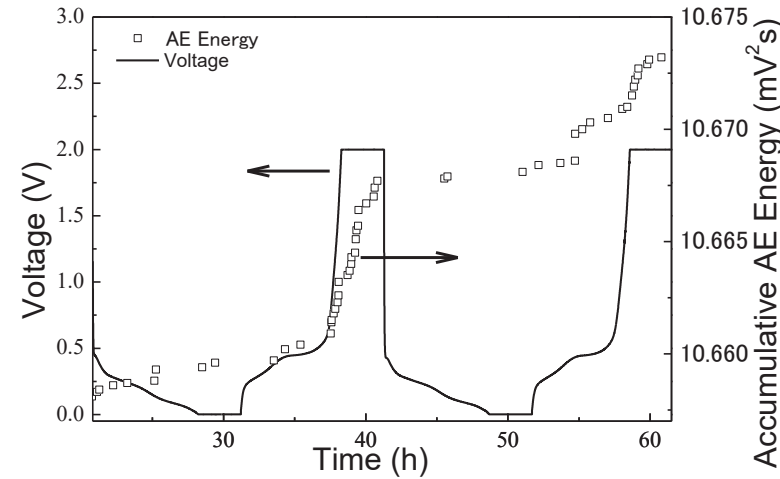

Fig. 10 Typical evolution of electrode potential and accumulated $\mathrm{AE}$ energy in 2nd and 3rd cycles.

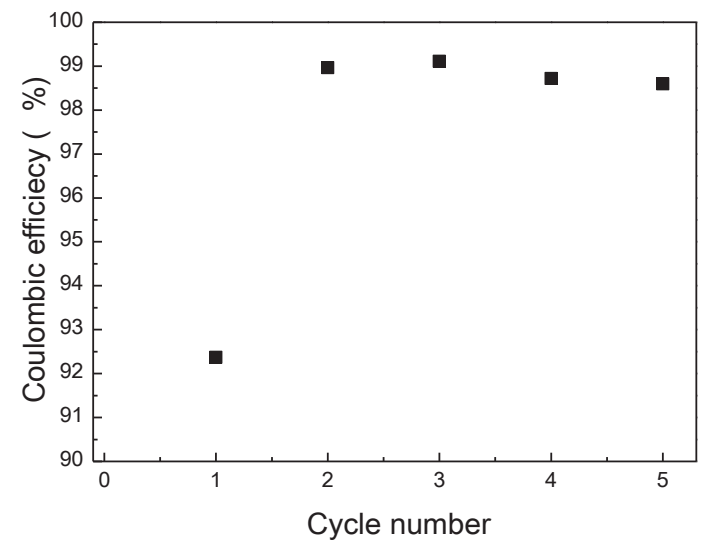

Fig. 11 Evolution of coulombic efficiency for amorphous silicon and crystalline silicon.

\section{4 結 言}

本研究では，アモルファス $\mathrm{Si}$ 負極の充放電に伴う劣化 挙動を詳細に観察することを目的に, 非破壊手法として $\mathrm{AE}$ 法を併用した電池セルの 5 サイクルまでの充放電サイ クル試験を行い，電気容量の劣化挙動を機械的損傷との 関係の観点から検討した，得られた主な結果を以下に列 記する.

1） $\mathrm{AE}$ 法を用いることで $\mathrm{Si}$ 負極の体積変化による機 械的損傷とそれが電池特性に与える影響をリア ルタイムで評価可能であることを示した．特に 1 サイクル目の充放電過程で多くの AE 信号が検出 され，特に層間反応層の形成が始まるとされる $0.4 \mathrm{~V}$ 付近で急激に増加した。

2） 発生した $\mathrm{AE}$ 信号は周波数特性の観点から 2 つの 種類のタイプに分類された。一つのタイプは充放 電時に生成されるガスの発生に起因し，もう一つ のタイプは Si 負極の機械的損傷によるものであ ることを明らかにした。また周波数解析の結果か
らガスの発生と Si 負極の損傷は同時に起きてい ることが確認された。

3） $\mathrm{AE}$ 活性度は初期充放電時に卓越し，それ以降は 急激に安定することが観察された。この傾向は充 放電サイクルに伴う容量劣化の傾向と類似して おり,電気的容量劣化は $\mathrm{Si}$ 負極の機械的損傷なら びにガス発生により生じることがわかった。

本研究の一部は, 科研費基盤研究 (B) （No. 16H04228， 16H04229）の支援により行われました.

\section{参 考 文 献}

1) D. Aurbach, B. Markovsky, I. Weissman, E. Levi and Y. Ein-Eli, "On the correlation between surface chemistry and performance of graphite negative electrodes for $\mathrm{Li}$ ion batteries", Electrochimica Acta, Vol.45, No.1, pp.67-86 (1999).

2) M. N. Obrovac and L. Christensen, "Structural changes in silicon anodes during lithium insertion/extraction", Electrochemical and Solid-State Letters, Vol. 7, No.5, pp.A93-A96 (2004).

3) J. P. Maranchi, A. F. Hepp and P. N. Kumta, "High capacity reversible silicon thin-film anodes for lithium-ion batteries", Electrochemical and Solid-State Letters, Vol.6, No.9, pp.A198-A201 (2003).

4) K. Rhodes, N. Dudney, E. Lara-Curzio and C. Daniel, "Understanding the degradation of silicon electrodes for lithium-ion batteries using acoustic emission", Journal of The Electrochemical Society, Vol.157, No.12, pp.A1354-A1360 (2010)

5) A. Tranchot, A. Etiemble, P. X. Thivel, H. Idrissi and L. Roue, "In-situ acoustic emission study of Si-based electrodes for Li-ion batteries", Journal of Power Sources, Vol.279, pp.259-266 (2015).

6) X. H. Liu, L. Zhong, S. Huang, S. X. Mao, T. Zhu and J. Y. Huang, "Size-dependent fracture of silicon nanoparticles during lithiation", ACS Nano, Vol.6, No.2, pp.1522-1531 (2012).

7) H. Wu, G. Chan, J. W. Choi, I. Ryu, Y. Yao, M. T. McDowell, S. W. Lee, A. Jackson, Y. Yang, L. Hu and Y. Cui, "Stable cycling of double-walled silicon nanotube battery anodes through solid-electrolyte interphase control", Nature Nanotechnology, Vol.7, No.5, pp.310-315 (2012).

8) C. K. Chan, H. Peng, G. Liu K. McIlwrath, X. F. Zhang, R. A. Huggins and Y. Cui, "High-performance lithium battery anodes using silicon nanowires", Nature nanotechnology, Vol.3, No.1, pp.31-35 (2008).

9) L. Cui, Y. Yang, C. Hsu and Y. Cui, "Carbon - silicon core - shell nanowires as high capacity electrode for lithium ion batteries", Nano letters, Vol.9, No.9, pp.3370-3374 (2009).

10) K. Rhodes, M, Kirkham, R. Meisner, C. M. Parish, N. Dudney and C. Daniel, "Novel cell design for combined in situ acoustic emission and x-ray diffraction study during electrochemical cycling of batteries", Review of 
$\begin{array}{lll}\text { Scientific Instruments, } & \text { Vol.82, } & \text { No.7, }\end{array}$ pp.075107-1-075107-7 (2011).

11) T. Ohzuku, H. Tomura and K. Sawai, "Monitoring of particle fracture by acoustic emission during charge and discharge of $\mathrm{Li} / \mathrm{MnO}_{2}$ cells", Journal of The Electrochemical Society, Vol.144, No.10, pp.3496-3500 (1997).

12) N. Kircheva, S. Genies, C. Chabrol and P. X. Thivel, "Evaluation of acoustic emission as a suitable tool for aging characterization of $\mathrm{LiAl} / \mathrm{LiMnO} 2$ cell", Electrochimica Acta, Vol.88, No.18, pp.488-494 (2013).

13) C. Villevieille, M. Boinet and L. Monconduit, "Direct evidence of morphological changes in conversion type electrodes in Li-ion battery by acoustic emission", Electrochemistry Communications, Vol.12, No.10, pp.1336-1339 (2010).

14) S. K. Soni, B. W. Sheldon, X. Xiao and A. Tokranov, "Thickness effects on the lithiation of amorphous silicon thin films", Scripta Materialia, Vol.64, No.4, pp.307-310 (2011)

15) M. T. McDowell, S. W. Lee, S. W. Harris, B. A. Korgel and Y. Cui, "In situ TEM of two-phase lithiation of amorphous silicon nanospheres", Nano Letters, Vol.13, No.2,pp.758-764 (2013).

16) S. W. Lee, M. T. McDowell, J. W. Choi and Y. Cui, "Anomalous shape changes of silicon nanopillars by electrochemical lithiation", Nano Letters, Vol.11, No.7, pp.3034-3039 (2011)

17) P. R. Raimann, N. S. Hochgatterer, C. Korepp,K. C. Möller, M. Winter, H. Schröttner and J. O. Besenhard, "Monitoring dynamics of electrode reactions in Li-ion batteries by in situ ESEM", Ionics, Vol.12, No.4-5, pp.253-255 (2006).

18) L. Y. Beaulieu, K. W. Eberman, R. L. Turner, L. J. Krause and J. R. Dahn, " Colossal reversible volume changes in lithium alloys", Electrochemical and Solid-State Letters, Vol.4, No.9, pp.A137-A140 (2001).

19) H. Nakasa,"Theoretical bases and practical applications of acoustic emission”, Chijin Shokan Co.,Ltd., (1994).

20) K. Ogata, E. Salager, C. J. Kerr, A. E. Fraser, C. Ducati, A. J. Morris and C. P. Grey," Revealing lithium-silicide phase transformations in nano-structured silicon-based lithium ion batteries via in situ NMR spectroscopy", Nature Communications, Vol.5, pp.3217 (2014).

21) H. Ghassemi, M. Au, N. Chen, P. A. Heiden and R. S. Yassar, "In situ electrochemical lithiation/delithiation observation of individual amorphous Si nanorods", ACS Nano, Vol.5, No.10 pp.7805-7811 (2011).

22)B. Key, R. Bhattacharyya, M. Morcrette, V. Seznec, J. M. Tarascon and C. P. Grey, "Real-time NMR investigations of structural changes in silicon electrodes for lithium-ion batteries", Journal of the American Chemical Society, Vol.13, No.26 pp.9239-9249 (2009).

23) T. D. Hatchard and J. R. Dahn, "In situ XRD and electrochemical study of the reaction of lithium with amorphous silicon", Journal of The Electrochemical S ociety, Vol.151, No.6 pp.A838-A842 (2004).

24) N. Yoshida, T. Sakamoto, N. Kuwata, J. Kawamura, K. Sato and T. Hashida, "In situ evaluation of mechanical and electrochemical degradation in silicon negative electrode for lithium-ion secondary batteries", 16th International Conference on Nanotechnology - IEEE NANO 2016, pp.974-977 (2016).

25) T. Fukushima, S. Kato, N. Kuwata and J. Kawamura, "In-situ acoustic emission study of $\mathrm{Sn}$ anode in $\mathrm{Li}$ ion battery”, ECS Transactions, Vol 62 pp.215-222 (2014).

26) J. Xie, N. Imanishi, T. Zhang, A. Hirano, Y. Takeda and O. Yamamoto, "Li-ion diffusion in amorphous Si films prepared by RF magnetron sputtering: A comparison of using liquid and polymer electrolytes", Materials Chemistry and Physics, Vol.120, No.2-3 pp.421-425 (2010). 